\title{
Crystal structure of 3-(4-hydroxy-3-methoxyphenyl)-7,7-dimethyl-7,8- dihydrocinnolin-5(6H)-one
}

\author{
Jabbar Khalafy $^{\mathrm{a}^{*}}$, Mehdi Rimaz ${ }^{\mathrm{b}}$, Mahnaz Ezzati ${ }^{\mathrm{a}}$ and Ahmad Poursattar Marjani ${ }^{\mathrm{a}}$
}

${ }^{a}$ Department of Chemistry, Faculty of Science, Urmia University, Urmia 57154, Urmia, Iran ${ }^{b}$ Department of Chemistry, Payame Noor University, PO Box 19395-3697, Tehran, Iran

\section{H R O N I C L E}

Article history:

Received June 25, 2012

Received in Revised form

November 6, 2012

Accepted 30 November 2012

Available online

30 November 2012

Keywords:

Arylglyoxal

Dimedone

Crystal Structure

Hydrogen bond

Cinnoline

\begin{abstract}
A B S T R A C T
The title compound 3-(4-hydroxy-3-methoxyphenyl)-7,7-dimethyl-7,8-dihydrocinnolin-5(6H)one (3) was prepared via one-pot three component reaction of 2-(4-hydroxy-3-methoxyphenyl)2-oxoacetaldehyde with dimedone in the presence of hydrazine hydrate and studied by the single crystal X-ray diffraction method. Its structure was also confirmed by $\mathrm{IR},{ }^{1} \mathrm{H}$ and ${ }^{13} \mathrm{C}$ NMR spectroscopy. Compound 3 was crystallized in the monoclinic system, space group $P 2{ }_{1} / c$, $a=7.921(2) \AA, b=11.566(4) \AA, c=16.986(6) \AA, \beta=107.338(5)^{\circ}, V=1485.5(8) \AA^{3}, Z=4, \mathrm{R} 1$ $=0.0559$ and $w R 2=0.1253$. The crystal structure of 3 also shows a weak interaction between $\mathrm{O} 3$ and $\mathrm{N} 2$ atoms.
\end{abstract}

\section{Introduction}

Cinnolines and their derivatives exhibit a broad range of biological activity, such as anticancer, fungicidal, bactericidal, and anti-inflammatory properties. ${ }^{1}$ Furthermore, compounds containing a cinnoline fragment demonstrate a series of interesting physical characteristics, such as luminescent and nonlinear optical properties. ${ }^{2}$ Hence, the synthesis of cinnoline has been studied for many years. ${ }^{3}$ Most syntheses of cinnolines involve arenediazonium salts, ${ }^{4}$ arylhydrazones, ${ }^{5}$ arylhydrazines, ${ }^{6}$ and nitriles $^{7}$ as their starting materials. Recently, alkynyl-substituted aryltriazene was used as the precursor to prepare cinnoline, ${ }^{8}$ however high temperatures or strong acidic conditions were still required. Palladium-catalyzed annulation of alkynes by functionally substituted aryl halides has been demonstrated to be a versatile methodology to construct a wide variety of complicated hetero- and

* Corresponding author. Fax : +98 4412776707

E-mail addresses: jkhalafi@yahoo.com; j.khalafi@urmia.ac.ir(J Khalafy)

C 2013 Growing Science Ltd. All rights reserved. doi: $10.5267 /$ j.ccl.2012.11.002 
carbocycles. ${ }^{9}$ Cinnoline frameworks have been recently obtained via palladium catalyzed reaction of 2 -iodotriazenes with internal alkynes. ${ }^{10}$ These procedures often suffer from certain drawbacks such as multi step reactions, harsh reaction conditions and using expensive catalysts. Therefore, these reported annulation reactions prompted us to investigate a single green reaction to prepare cinnoline rings.

In continuation of our recent reports on synthesis of pyridazine derivatives, ${ }^{11-18}$ here we report the X-ray crystal structure of 3-(4-hydroxy-3-methoxyphenyl)-7,7-dimethyl-7,8-dihydrocinnolin-5(6H)one prepared by reaction of 2-(4-hydroxy-3-methoxyphenyl)-2-oxoacetaldehyde with dimedone in the presence of hydrazine hydrate. ${ }^{11}$

\section{Results and Discussion}

2-(4-Hydroxy-3-methoxyphenyl)-2-oxoacetaldehyde (1) was reacted with dimedone (2) in the presence of hydrazine hydrate in water at $5-8{ }^{\circ} \mathrm{C}$, which led to form 3-(4-hydroxy-3-methoxyphenyl)7,7-dimethyl-7,8-dihydrocinnolin-5(6H)-one (3) (Scheme 1).<smiles>COc1cc(C(=O)C=O)ccc1O</smiles>

1

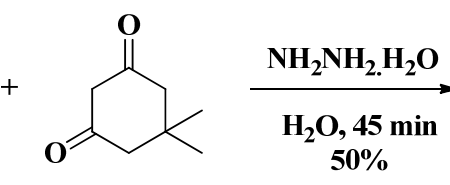

2<smiles>COc1cc(-c2cc3c(nn2)CC(C)(C)CC3=O)ccc1O</smiles>

3

\section{Scheme 1}

The proposed mechanism for the synthesis of final compound (3) is shown in Scheme 2.

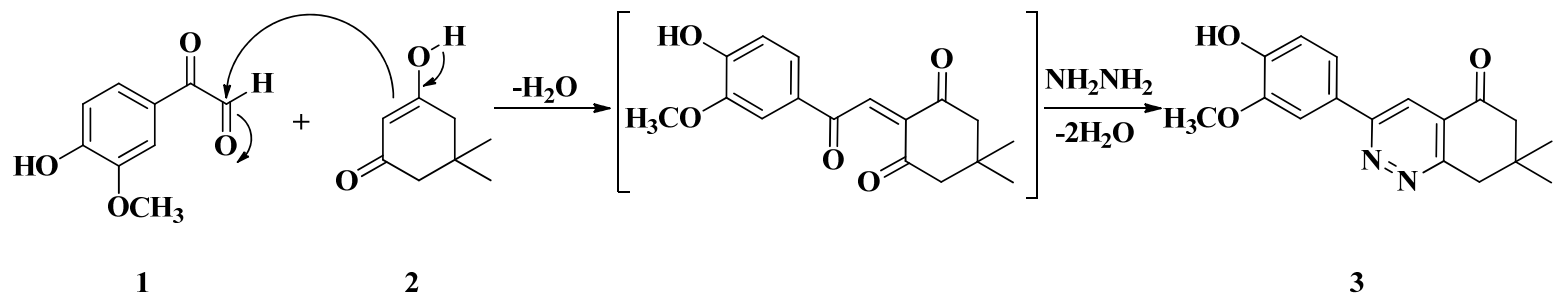

Scheme 2

In the ${ }^{1} \mathrm{H}-\mathrm{NMR}$ spectrum of this compound, the $\mathrm{CH}$ on pyridazine ring is very deshielded and resonates at low field. The corresponding proton appears at $\delta=8.24 \mathrm{ppm}$.

\section{Crystal structure determination of 3}

The crystal structure of $\mathbf{3}$ is shown in Fig. 1. Single-crystals of $\mathbf{3}$ were used for data collection on a Bruker Smart Apex diffractometer using SMART software. ${ }^{19}$ Suitable crystals were selected and mounted on a glass fiber using epoxy-based glue. The data sets were collected at room temperature for sample employing a scan of $0.3^{\circ}$ in $\omega$ with an exposure time of $20 \mathrm{~s} /$ frame. The cell refinement and data reduction were carried out with SAINT, ${ }^{20}$ the program SADABS was used for the absorption correction. ${ }^{20}$ The structure was solved by direct methods using SHELXS-97, ${ }^{21}$ and difference Fourier syntheses. Full-matrix least-squares refinement against $\left|\mathrm{F}^{2}\right|$ was carried out using the SHELXTLPLUS, ${ }^{21}$ suit of programs. All non-hydrogen atoms were refined anisotropically. Hydrogen atoms were placed geometrically and held in the riding mode during the final refinement. The crystallographic data for structure 3 were deposited to the Cambridge Crystallographic Data Center 
(entry no. CCDC-894314) and are available free of charge upon request to CCDC, 12 Union Road, Cambridge, UK (Fax: +44-1223-336033, e-mail: deposit@ccdc.cam.ac.uk).

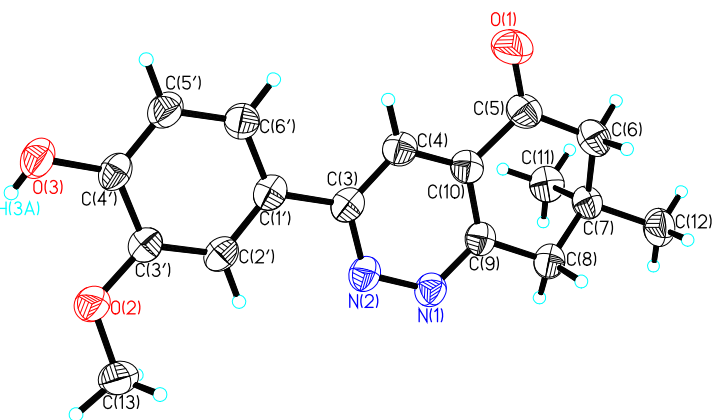

Fig. 1. Crystal structure of compound 3.

Table 1. Crystal data and structure refinement details for 3.

\begin{tabular}{|c|c|}
\hline Empirical formula & $\mathrm{C}_{17} \mathrm{H}_{18} \mathrm{~N}_{2} \mathrm{O}_{3}$ \\
\hline Formula weight & 298.33 \\
\hline Crystal size, $\mathrm{mm}^{3}$ & $0.40 \times 0.20 \times 0.08$ \\
\hline Crystal color and form & orange, diamond \\
\hline Crystal system & monoclinic \\
\hline Space group & $P 2{ }_{1} / c$ \\
\hline$a, b, c, \mathrm{~A}^{\circ} ; \beta, \operatorname{deg}$ & $7.921(2), 11.566(4), 16.986(6), 107.338(5)$ \\
\hline$V, \mathrm{~A}^{03}$ & $1485.5(8)$ \\
\hline Z & 4 \\
\hline $\mathrm{D}$ (calc), g.cm ${ }^{-3}$ & 1.334 \\
\hline$\mu, \mathrm{mm}^{-1}$ & 0.092 \\
\hline $\mathrm{F}(000)$, e & 632 \\
\hline Scan type & $\omega$ \\
\hline$\theta$ range, deg & $2.16-28.34$ \\
\hline \multirow[t]{2}{*}{ Index range } & $-10<\mathrm{h}<10,-15<\mathrm{k}<15$ \\
\hline & $-22<1<22$ \\
\hline Measured reflections & 18028 \\
\hline Independent reflections & 3702 \\
\hline Observed refl. $\mathrm{I} \geq 2 \sigma(\mathrm{I})$ & 1710 \\
\hline Completeness to $\theta=28.34^{\circ}$ & 99.5 \\
\hline Refinement on & $F^{2}$ \\
\hline Data, restraints, parameters & $3702,0,199$ \\
\hline $\mathrm{R}\left(\mathrm{Fo}^{2}>2 \sigma\left(\mathrm{Fo}^{2}\right)\right)$ & $R 1=0.0559, \mathrm{w} R 2=0.1253$ \\
\hline $\mathrm{R}$ (all data) & $R 1=0.1326, w R 2=0.1584$ \\
\hline Goodness-of-fit $=S$ & 0.0993 \\
\hline Weighting parameter $a / b$ & $0.0416 / 0.1303$ \\
\hline$\Delta \rho(\max ; \min )$, e. $\mathrm{A}^{\circ-3}$ & $0.9926 ; 0.9639$ \\
\hline
\end{tabular}

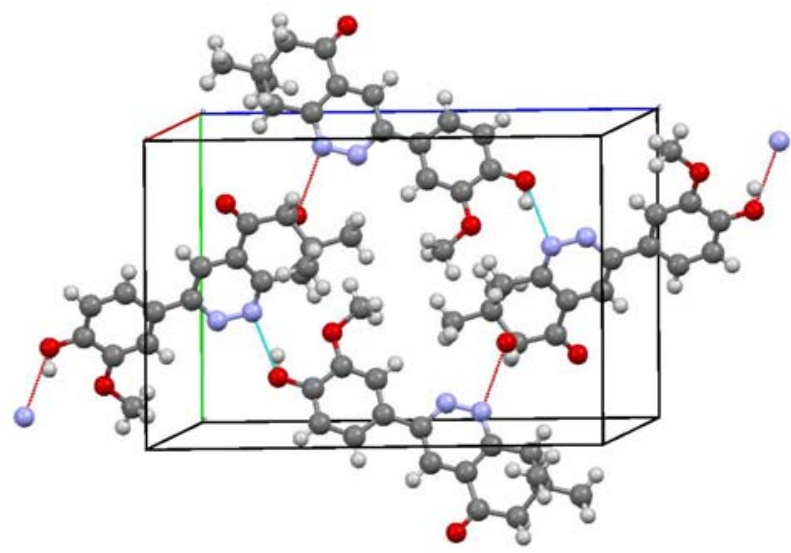

Fig. 2. Crystal packing diagram of 3 with intermolecular hydrogen bond. 


\section{Description of the crystal 3}

The crystal structure of $\mathbf{1}$ and its crystal packing diagram are shown in Figs. 1 and 2, respectively. A summary of the crystal data and experimental details is given in Table 1. The selected bond lengths and angles for $\mathbf{3}$ are shown in Table 2. The geometry hydrogen bonds are shown in Table 3 . The crystal structure of 3 also shows a weak interaction between $\mathrm{O} 3$ and $\mathrm{N} 2$ atoms. The dimedone and pyridazine rings moieties are not in the same plane together. The torsion angles of $\mathrm{C} 6-\mathrm{C} 7-\mathrm{C} 8-\mathrm{C} 9$, $\mathrm{C} 5-\mathrm{C} 6-\mathrm{C} 7-\mathrm{C} 8$ are $50.3^{\circ}$ and $-55.8^{\circ}$, respectively. The angles of C6-C7-C8, C10-C4-C3 and N1-C9$\mathrm{C} 8$ are $108.12,118.9$ and $117.06^{\circ}$ respectively. The carbonyl group in dimedone lies in plane of pyridazine ring. The Bond lengths of $\mathrm{N} 1-\mathrm{N} 2$ and $\mathrm{N} 2-\mathrm{C} 3$ are 1.339 and 1.337 respectively for interaction of $\mathrm{O} 3$ with $\mathrm{N} 2$. The torsion angles of $\mathrm{C} 9-\mathrm{N} 1-\mathrm{N} 2-\mathrm{C} 3, \mathrm{~N} 2-\mathrm{C} 3-\mathrm{C} 1{ }^{\prime}-\mathrm{C} 2$ ' equals to $0.5^{\circ}$ and $2.8^{\circ}$, respectively.

Table 2. Selected bond lengths and angles $\left(\AA,^{\circ}\right)$ of 3 .

\begin{tabular}{|c|c|c|c|}
\hline Bond & & Angle & \\
\hline $\mathrm{N}(1)-\mathrm{C}(9)$ & $1.338(2)$ & $\mathrm{C}(9)-\mathrm{N}(1)-\mathrm{N}(2)$ & $120.47(17)$ \\
\hline $\mathrm{N}(1)-\mathrm{N}(2)$ & $1.339(2)$ & $\mathrm{C}(3)-\mathrm{N}(2)-\mathrm{N}(1)$ & $120.69(18)$ \\
\hline $\mathrm{N}(2)-\mathrm{C}(3)$ & $1.337(2)$ & $\mathrm{N}(2)-\mathrm{C}(3)-\mathrm{C}(4)$ & $120.60(19)$ \\
\hline$C(3)-C\left(1^{\prime}\right)$ & $1.476(3)$ & $\mathrm{N}(2)-\mathrm{C}(3)-\mathrm{C}\left(1^{\prime}\right)$ & $115.72(19)$ \\
\hline$C(4)-C(10)$ & $1.362(3)$ & $\mathrm{C}(10)-\mathrm{C}(4)-\mathrm{C}(3)$ & $118.9(2)$ \\
\hline $\mathrm{C}(4)-\mathrm{H}(4 \mathrm{~A})$ & 0.93 & $\mathrm{C}(10)-\mathrm{C}(4)-\mathrm{H}(4 \mathrm{~A})$ & 120.6 \\
\hline $\mathrm{C}(5)-\mathrm{O}(1)$ & $1.216(2)$ & $\mathrm{O}(1)-\mathrm{C}(5)-\mathrm{C}(10)$ & $120.1(2)$ \\
\hline$C(5)-C(6)$ & $1.487(3)$ & $C(6)-C(5)-C(10)$ & $116.7(2)$ \\
\hline$C(5)-C(10)$ & $1.498(3)$ & $C(5)-C(6)-C(7)$ & $114.65(18)$ \\
\hline$C(6)-C(7)$ & $1.529(3)$ & $\mathrm{C}(11)-\mathrm{C}(7)-\mathrm{C}(12)$ & $110.00(18)$ \\
\hline $\mathrm{C}(6)-\mathrm{H}(6 \mathrm{~A})$ & 0.97 & $C(11)-C(7)-C(6)$ & $109.94(18)$ \\
\hline $\mathrm{C}(6)-\mathrm{H}(6 \mathrm{~B})$ & 0.97 & $C(6)-C(7)-C(8)$ & $108.12(17)$ \\
\hline $\mathrm{C}(7)-\mathrm{C}(12)$ & $1.528(3)$ & $\mathrm{N}(1)-\mathrm{C}(9)-\mathrm{C}(10)$ & $121.07(19)$ \\
\hline$C(7)-C(8)$ & $1.531(3)$ & $\mathrm{N}(1)-\mathrm{C}(9)-\mathrm{C}(8)$ & $117.06(18)$ \\
\hline $\mathrm{C}(9)-\mathrm{C}(10)$ & $1.397(3)$ & $C(4)-C(10)-C(5)$ & $121.63(19)$ \\
\hline$C\left(1^{\prime}\right)-C\left(6^{\prime}\right)$ & $1.381(3)$ & $\mathrm{C}(9)-\mathrm{C}(10)-\mathrm{C}(5)$ & $120.09(19)$ \\
\hline $\mathrm{C}\left(1^{\prime}\right)-\mathrm{C}\left(2^{\prime}\right)$ & $1.400(3)$ & $\mathrm{C}\left(6^{\prime}\right)-\mathrm{C}\left(1^{\prime}\right)-\mathrm{C}\left(2^{\prime}\right)$ & $117.70(19)$ \\
\hline $\mathrm{C}\left(3^{\prime}\right)-\mathrm{O}(2)$ & $1.373(2)$ & $C\left(6^{\prime}\right)-C\left(1^{\prime}\right)-C(3)$ & $122.5(2)$ \\
\hline $\mathrm{C}\left(3^{\prime}\right)-\mathrm{C}\left(4^{\prime}\right)$ & $1.388(3)$ & $\mathrm{C}\left(2^{\prime}\right)-\mathrm{C}\left(3^{\prime}\right)-\mathrm{O}\left(2^{\prime}\right)$ & $124.79(19)$ \\
\hline $\mathrm{C}\left(4^{\prime}\right)-\mathrm{O}(3)$ & $1.351(2)$ & $\mathrm{O}(2)-\mathrm{C}\left(3^{\prime}\right)-\mathrm{C}\left(4^{\prime}\right)$ & $114.48(18)$ \\
\hline$C\left(4^{\prime}\right)-C\left(5^{\prime}\right)$ & $1.377(3)$ & $\mathrm{O}(3)-\mathrm{C}\left(4^{\prime}\right)-\mathrm{C}\left(5^{\prime}\right)$ & $118.60(19)$ \\
\hline $\mathrm{C}\left(5^{\prime}\right)-\mathrm{H}\left(5^{\prime} \mathrm{A}\right)$ & 0.93 & $\mathrm{O}(3)-\mathrm{C}\left(4^{\prime}\right)-\mathrm{C}\left(3^{\prime}\right)$ & $122.9(2)$ \\
\hline $\mathrm{O}(2)-\mathrm{C}(13)$ & $1.422(2)$ & $\mathrm{O}(2)-\mathrm{C}(13)-\mathrm{H}(13 \mathrm{~A})$ & 109.5 \\
\hline $\mathrm{O}(3)-\mathrm{H}(3 \mathrm{~A})$ & 0.82 & $\mathrm{C}\left(4^{\prime}\right)-\mathrm{O}(3)-\mathrm{H}(3 \mathrm{~A})$ & 109.5 \\
\hline
\end{tabular}

Table 3. Hydrogen bond geometry in $3\left(\AA,{ }^{\circ}\right)$.

\begin{tabular}{ccccc}
\hline $\mathbf{D}-\mathbf{H} \cdots \mathbf{A}$ & $\boldsymbol{d}(\mathbf{D}-\mathbf{H})$ & $\boldsymbol{d}(\mathbf{H} \cdots \mathbf{A})$ & $\boldsymbol{d}(\mathbf{D} \cdots \mathbf{A})$ & $\mathbf{D}-\mathbf{H} \cdots \mathbf{A}$ \\
\hline $\mathrm{O}(3)-\mathrm{H}(3 \mathrm{~A}) \ldots \mathrm{N}(1) \mathrm{i}$ & 0.82 & 1.99 & $2.742(2)$ & 151.6 \\
$\mathrm{O}(3)-\mathrm{H}(3 \mathrm{~A}) \ldots \mathrm{N}(2) \mathrm{i}$ & 0.82 & 2.64 & $3.171(2)$ & 123.9 \\
\hline
\end{tabular}

Symmetry codes: (i) $x,-y+1 / 2, z+1 / 2$

\section{Acknowledgements}

The authors are grateful to Urmia University for financial support and to Dr. A. Choudhury (Missouri University of Science and Technology, USA) for his assistance with X-ray crystallography. 


\section{Experimental}

Materials and Instruments. Melting point was determined on a digital melting point apparatus (Electrothermal) and remains uncorrected. Infrared spectra were recorded on a Thermo Nicolet (Nexus 670) FT-IR spectrometer, using KBr disks. ${ }^{1} \mathrm{H}$ and ${ }^{13} \mathrm{C}$ NMR spectra were recorded with a Bruker spectrometer at 300 and $75.5 \mathrm{MHz}$, respectively. The spectra were measured in $\mathrm{CDCl}_{3}$ using TMS as the internal standard.

Synthesis of 3-(4-hydroxy-3-methoxyphenyl)-7,7-dimethyl-7,8-dihydrocinnolin-5(6H)-one (3).

To a mixture of dimedone $(1 \mathrm{mmol})$ and 2-(4-hydroxy-3-methoxyphenyl)-2-oxoacetaldehyde (1 $\mathrm{mmol})$ in water $(5 \mathrm{~mL})$, was successively added hydrazine hydrate $100 \%(3 \mathrm{mmol})$ at $5-8{ }^{\circ} \mathrm{C}$. The reaction mixture was stirred for 20-40 minutes. The solid was filtered then recrystallized from ethanol to give the title compound as yellow crystals $(50 \%), \mathrm{mp} 127{ }^{\circ} \mathrm{C} .{ }^{1} \mathrm{H}$ NMR $\left(\mathrm{CDCl}_{3}\right) \delta(\mathrm{ppm}): 8.24(\mathrm{~s}$, $1 \mathrm{H}, \operatorname{Ar}), 7.91(\mathrm{~s}, 1 \mathrm{H}, \mathrm{Ar}), 7.57$ (d, $J=8.4 \mathrm{~Hz}, 1 \mathrm{H}, \mathrm{Ar}), 7.06(\mathrm{~d}, J=8.4 \mathrm{~Hz}, 1 \mathrm{H}, \mathrm{Ar}), 5.96$ (bs, $1 \mathrm{H}$, $\mathrm{OH}), 4.02\left(\mathrm{~s}, 3 \mathrm{H}, \mathrm{OCH}_{3}\right), 3.32\left(\mathrm{~s}, 2 \mathrm{H}, \mathrm{CH}_{2}\right), 2.65\left(\mathrm{~s}, 2 \mathrm{H}, \mathrm{CH}_{2}\right), 1.17\left(\mathrm{~s}, 6 \mathrm{H}, 2 \times \mathrm{CH}_{3}\right) .{ }^{13} \mathrm{C} \mathrm{NMR}$ $\left(\mathrm{CDCl}_{3}\right) \delta(\mathrm{ppm}): 197.95,159.08,158.55,148.03,147.26,127.92,127.67,120.41,118.22,114.83$, 109.21, 56.15, 52.23, 43.21, 33.07, 28.23. FT-IR $v_{\max }$ 3390, 3063, 3008, 2951, 2865, 2631, 1703, 1589, 1514, 1460, 1408, 1335, 1275, 1208, 1128, 1029, 872, $796 \mathrm{~cm}^{-1}$. Mass spectrum $\mathrm{m} / \mathrm{z}(\%): 298$ [M+ , 7], 297 (8), 280 (17), 265 (13), 251 (32), 237 (12), 202 (11), 167 (18), 149 (49), 115 (16), 97 (24), 83 (37), 69 (73), 57 (83), 43 (100).

\section{References}

1. (a) Yu, Y., Singh, S. K., Liu, A., Li, T.-K., Liu, L. F., and La Voie, E. J. (2003) Substituted dibenzo[c,h]cinnolines: topoisomerase I-targeting anticancer agents, Bioorg. Med. Chem.,11, 1475-1491; (b) Ruchelman, A. L., Sing, S. K., Ray, A., Wu, X., Yang, J. M., Zhu, N., Liu, A., Liu, L. F., and LaVoie, E. J. (2004) 11H-Isoquino[4,3-c]cinnolin-12-ones: novel anticancer agents with potent topoisomerase I-targeting activity and cytotoxicity, Bioorg. Med. Chem., 12, 795-806; (c) Lunniss, C.; Eldred, C., Aston, N., Craven, A., Gohil, K., Judkins, B., Keeling, S., Ranshaw, L., Robinson, E., Shipley, T., and Trivedi, N. (2010) Addressing species specific metabolism and solubility issues in a quinoline series of oral PDE4 inhibitors, Bioorg. Med. Chem. Lett., 20, 137-140.

2. Chapoulaud, V. G., Plé, N., Turck, A., and Queguiner, G. (2000) Synthesis of 4,8Diarylcinnolines and Quinazolines with Potential Applications in Nonlinear Optics. Diazines. Part 28, Tetrahedron, 56, 5499-5507.

3. For the review about cinnoline synthesis, see: (a) Haider, N., and Holzer, W. (2004) Product Class 9: Cinnolines. Sci. Synth., 16, 251-313; (b) Vinogradova, O. V., and Balova, I. A. (2008) Methods for the synthesis of cinnolines, Chem. Heterocycl. Comp., 44, 501-522.

4. Cinnoline synthesis from arenediazonium salts: Vasilevsky, S. F., Tretyakov, E. V., and Verkruijsse, H. D. A (1994) Convenient Synthesis of 4-Chloro- and 4-Bromocinnolines from o-Aminophenylacetylenes, Synth. Commun., 24, 1733-1736.

5. Cinnoline synthesis from arylhydrazones: (a) Kiselyov, A. S. (1995) Trifluoromethyl group in the synthesis of heterocyclic compounds: New and efficient synthesis of 3-aryl-4aminocinnolines, Tetrahedron Lett., 36, 1383-1386; (b) Shvartsberg, M. S., and Ivanchikova, I. D. (2000) An unknown route of cyclocondensation of peri-acetylenylquinones with hydrazine, Tetrahedron Lett., 41, 771-773; (c) Gomaa, M. A. -M. (2003) An efficient and facile synthesis of substituted cinnoline and benzo[h]cinnoline derivatives, Tetrahedron Lett., 44, 3493-3496. 
6. Cinnoline synthesis from arylhydrazines: Alford, E. J., and Schofield, K. (1952) Cinnolines. Part XXVIII. The nature of the C(3)-position. Part I. The Neber-Bossel synthesis of 3-hydroxycinnoline, J. Chem. Soc., 2102-2108.

7. Cinnoline synthesis from nitrile: Chen, D., Yang, C., Xie, Y., and Ding, J. (2009) Novel Process to 4,4-Dialkyl-1,4-dihydro-6-methoxy-3-phenylcinnolines via Grignard Reaction, Heterocycles., 77, 273-277.

8. (a) Bräse, S., Gil, C., and Knepper, K. (2002) The recent impact of solid-phase synthesis on medicinally relevant benzoannelated nitrogen heterocycles, Bioorg. Med. Chem., 10, $2415-$ 2437; (b) Kimball, D. B., Weakley, T. J. R., Herges, R., and Haley, M. M. (2002) Deciphering the Mechanistic Dichotomy in the Cyclization of 1-(2-Ethynylphenyl)-3,3-dialkyltriazenes: Competition between Pericyclic and Pseudocoarctate Pathways, J. Am. Chem. Soc., 124, 13463-13473; (c) Kimball, D. B., Weakley, T. J. R., and Haley, M. M. (2002) Cyclization of 1-(2-Alkynylphenyl)-3,3-dialkyltriazenes: A Convenient, High-Yield Synthesis of Substituted Cinnolines and Isoindazoles, J. Org. Chem., 67, 6395-6405; (d) Vinogradovaa, O. V., Sorokoumova, V. N., and Balova, I. A. (2009) A short route to 3-alkynyl-4bromo(chloro)cinnolines by Richter-type cyclization of ortho-(dodeca-1,3-diynyl)aryltriaz-1enes, Tetrahedron Lett., 50, 6358-6360.

9. (a) Zeni, G., and Larock, R. C. (2006) Synthesis of Heterocycles via Palladium-Catalyzed Oxidative Addition, Chem. Rev., 106, 4644-4680; (b) Zeni, G., and Larock, R. C. (2004) Synthesis of Heterocycles via Palladium $\pi$-Olefin and $\pi$-Alkyne Chemistry, Chem. Rev., 104, 2285-2310.

10. Zhu, C., and Yamane, M. (2011) Synthesis of 3,4-disubstituted cinnolines by the Pd-catalyzed annulation of 2-iodophenyltriazenes with an internal alkyne, Tetrahedron., 67, 4933-4938.

11. Khalafy, J., Rimaz, M., Ezzati, M., and Prager, R. H. (2012) A Green One-Pot Protocol for Regioselective Synthesis of New Substituted 7,8-Dihydrocinnoline-5(6H)-ones, Bull. Korean Chem. Soc., 33, 2890-2896.

12. Khalafy, J., Rimaz, M., Panahi, L., and Rabiei, H. (2011). A regiospecific one-pot, three component synthesis of 4-aryl-6,8-dimethylpyrimido[4,5-c]pyridazine-5,7 $6 \mathrm{H}, 8 \mathrm{H})$-diones as new potential monoamine oxidase inhibitors, Bull. Korean Chem. Soc., 32, 2428-2432.

13. Rimaz, M., and Khalafy, J. (2010) Novel one-pot, three component synthesis of alkyl 6-aryl3-methylpyridazine-4-carboxylates in water. Arkivoc, ii, 110-117.

14. Rimaz, M., Khalafy, J., and Najafi Moghadam, P. (2010) A regioselective one-pot, three component synthesis of 6-aryl-4-cyano-3(2H)-pyridazinones in water. Aust. J. Chem., 63, 1396-1401.

15. Rimaz, M., Noroozi Pesyan, N., and Khalafy, J. (2010) Tautomerism and isotopic multiplets in the ${ }^{13} \mathrm{C}$ NMR spectra of partially deuterated 3-arylpyrimido[4,5-c]pyridazine-5,7 $(6 \mathrm{H}, 8 \mathrm{H})$ diones and their sulfur analogs-evidence for elucidation of the structure backbone and tautomeric forms, Magn. Reson. Chem., 48, 276-285.

16. Rimaz M., Khalafy J., Noroozi Pesyan N., and Prager R. H. (2010) A simple one-pot, three component synthesis of 3-arylpyrimido[4,5-c]pyridazine-5,7 $(6 \mathrm{H}, 8 \mathrm{H})$-diones and their sulfur analogues as potential monoamine oxidase inhibitors. Aust. J. Chem., 63, 507-510.

17. Khalafy, J., Rimaz, M., and Ezzati, M. (2012) Regioselective one-pot, three component synthesis of ethyl 6-aryl-3-propylpyridazine-4-carboxylates in water, Curr. Chem. Lett., 1, 115-122.

18. Khalafy, J., Parsa Habashi, B., Poursattar Marjani, A., and Najafi Moghadam, P. (2012) The synthesis of 2-arylquinoxaline derivatives, Curr. Chem. Lett., 1, 139-146.

19. Bruker, SMART. Bruker AXS Inc., Madison, Wisconsin, USA 2002.

20. Bruker SAINT and SADABS. Bruker AXS Inc., Madison, Wisconsin, USA, 2008.

21. Sheldrick, G. M. (2008) A short history of SHELX, Acta Cryst., A64, 112-122. 